\title{
STRATEGI PEMASARAN TAKSI BANDARA NGURAH RAI DENGAN METODE BGC (BOSTON CONSULTING GROUP)
}

\author{
Jontinus Naibaho ${ }^{1}$, I Gusti Putu Bagus Sasrawan Mananda ${ }^{2}$, Putu Agus Wikanatha Sagita ${ }^{3}$ \\ ${ }^{1}$ Email : jon.baho@ymail.com \\ Program Studi Industri Perjalanan Wisata, Fakultas Pariwisata, Universitas Udayana \\ 2Email : gusmananda@unud.ac.id \\ Program Studi Industri Perjalanan Wisata, Fakultas Pariwisata, Universitas Udayana \\ ${ }^{3}$ Email : aguswika@unud.ac.id \\ Program Studi Industri Perjalanan Wisata, Fakultas Pariwisata, Universitas Udayana
}

\begin{abstract}
The purpose of this research is to find out the right marketing strategies and competitiveness by identifying and analyzing the internal and external environment that affect the Ngurah Rai Airport Taxi Cooperative. In this study using marketing strategy analysis, namely BCG/Boston Consulting Group Matrix and SWOT (Strength, Weakness, Opportunity, Threats) analysis. BCG matrix to determine the level of market growth and relative market share. SWOT analysis to analyze strengths, weaknesses, opportunities and threats, then using segmenting, targeting, positioning/STP and 7P (marketing mix) results of the data obtained and then analyzed with IFAS and EFAS. The types of data used in this study are qualitative and quantitative data, primary and secondary data. Determination of samples in this study using purposive sampling method as many as 50 respondents. Data collection techniques by observation, questionnaires, structured interviews, and literature study. The results of the BCG matrix research, based on the calculation of the market growth rate is $1.35 \%$ and the result of the calculation of the relative market share is $1.45 \mathrm{x}>1$ so that it is in the position of Cash Cow. The marketing strategy that can be carried out by the Ngurah Rai Airport Taxi Cooperative is to maintain the market, create new products, find new businesses. The strategy offered in the Cash Cow quadrant the company must always keep the company in a stable condition. The results of the SWOT analysis study from IFAS assessment were 2.66 and EFAS was 2.28. Then the position of the SWOT diagram is Growth Stability which is the company must determine efforts to strengthen market share, increase sales, pursue large profits by diversifying/expanding the market.
\end{abstract}

\begin{abstract}
Abstrak: Tujuan penelitian ini untuk mengetahui strategi pemasaran yang tepat dan berdaya saing dengan mengidentifikasi dan menganalisis lingkungan internal dan eksternal yang mempengaruhi pada Koperasi Taksi Bandara Ngurah Rai. Pada penelitian ini menggunakan analisis strategi pemasaran yaitu Matrik BCG (Boston Consulting Group) dan analisis SWOT (Strength, Weakness, Opportunity, Threats). Matrik $B C G$ untuk mengetahui tingkat pertumbuhan pasar dan pangsa pasar relatif. Analisis SWOT untuk menganalisis kekuatan, kelemahan, peluang dan ancaman. kemudian menggunakan Segmenting, Targeting, Positioning/STP dan 7P (bauran pemasaran) hasil data yang diperoleh lalu dianalisis dengan IFAS dan EFAS. Jenis data yang digunakan dalam penelitian ini adalah data kualitatif dan kuantitatif, data primer dan sekunder. Penentuan sampel dalam penelitian ini menggunakan metode purposive sampling sebanyak 50 responden. Teknik pengumpulan data dengan cara observasi, kuesioner, wawancara berstruktur, dan studi kepustakaan . Hasil penelitian matrik $B C G$, berdasarkan hasil perhitungan tingkat pertumbuhan pasar adalah $1,35 \%$ dan hasil perhitungan pangsa pasar relatif adalah 1,45 x >1 sehingga berada di posisi Cash Cow (sapi perah). Strategi pemasaran yang dapat dilakukan oleh Koperasi Taksi Bandara Ngurah Rai adalah memelihara pasar, menciptakan produk baru, mencari bisnis baru. Strategi yang ditawarkan pada kuadran Cash Cow perusahaan harus selalu menjaga agar perusahaan dalam kondisi stabil. Hasil penelitian Analisis SWOT dari penilaian IFAS adalah 2,66 dan EFAS adalah 2,28. Maka posisi diagram SWOT adalah Growth Stability, yaitu perusahaan harus menetapkan upaya-upaya dalam memperkuat pangsa pasar, meningkatkan penjualan, mengejar laba yang besar dengan upaya diversivikasi/perluasan pasar.
\end{abstract}

Keywords: marketing strategy, BCG matrix, SWOT. 


\section{PENDAHULUAN}

Industri pariwisata saat ini sangat berkembang pesat, kebutuhan akan pentingnya kegiatan berwisata semakin tinggi. Dalam memenuhi kebutuhan tersebut banyak orang melakukan kegiatan wisata, baik di dalam suatu negara maupun keluar meninggalkan negara asal menuju negara tujuan wisatanya.

Bali merupakan salah satu daerah tujuan wisata yang memiliki sejuta pesona dan keindahan alamnya. Bali dikenal dengan berbagai macam sebutan seperti "Pulau Surga", "Pulau Dewata", "Pulau Seribu Pura" dan masih banyak yang lainnya. Bali mendapat sebutan tersebut karena keindahan pulaunya, mempunyai ciri khas budaya yang sangat berbeda dan memiliki banyak Pura besar yang memiliki nilai heritage yang tinggi. Oleh sebab itu Bali di kenal sebagai destinasi pariwisata yang tersohor hingga ke mancanegara, maka dari itu jumlah kunjungan wisatawan ke Bali cenderung mengalami peningkatan tiap tahunnya. Bali telah berhasil menarik wisatawan domestik maupun wisatawan mancanegara untuk berlibur di pulau seribu pura ini. Pertumbuhan kunjungan wisatawan dari tahun 2012-2016 mengalami fluktuasi dengan rata-rata pertumbuhan $8,99 \%$.

Sektor transportasi merupakan salah satu komponen yang harus ada di dalam industri pariwisata. Dimana dalam melakukan suatu perjalanan wisata, wisatawan akan membutuhkan sarana transportasi baik transportasi darat, udara, maupun laut yang bermanfaat untuk memudahkan wisatawan yang akan pergi menuju sebuah destinasi atau daerah tujuan wisatanya.

Langkah strategis yang dapat dilakukan oleh perusahaan transportasi adalah dengan menyusun suatu rencana yang komprehensif dan menyeluruh disertai dengan berbagai kebijaksanaan untuk dijadikan sebagai pedoman oleh perusahaan dalam mengimplementasikan rencana. Penyusunan rencana komprehensif yang dimaksud.

Salah satu upaya yang dilakukan oleh perusahaan transportasi dalam melakukan pemasaran adalah dengan merumuskan sebuah strategi pemasaran. Strategi pemasaran memiliki peran yang penting untuk keberhasilan perusahaan. Oleh karena itulah strategi pemasaran harus dapat memberikan gambaran yang jelas dan teratur tentang apa yang dilakukan oleh perusahaan dan menggunakan setiap kesempatan atau peluang pada beberapa sasaran pasar

Koperasi Taksi Bandara Ngurah Rai merupakan sebuah perusahaan yang bergerak di bidang transportasi dan salah satu outlet operasionalnya berada di Bandara Ngurah Rai. Beroperasinya usaha transportasi ini dikawasan Bandara Ngurah Rai akan memberikan kemudahan bagi wisatawan yang akan berlibur di pulau Bali

Koperasi Taksi Bandara Ngurah Rai mengalami berbagai masalah dan tantangantantangan yang bersumber baik dari dalam maupun dari luar perusahaan. Tingginya tingkat persaingan usaha transportasi khususnya yang beroperasi dikawasan Bandara Ngurah Rai mengakibatkan terjadinya penurunan pendapatan oleh Koperasi Taksi Bandara Ngurah Rai. Hal ini dapat dilihat dari data jumlah penumpang yang mengalami fluktuasi setiap tahunnya dalam 10 tahun terakhir (2007-2016) yang menunjukkan bahwa data dari tahun 2007 - 2016 mengalami fluktuasi, namun pada tahun 2016 drastis terjadi penurunan dengan jumlah penumpang yang menggunakan jasa taksi sebanyak 213.984, dari data ini mengalami penurunan sebesar 115.567, jika dibandingkan dengan tahun sebelumnya yaitu 356.546 penumpang.

Faktor yang menyebabkan turunnya penjualan karena ketatnya persaingan dimana banyaknya perusahaan pesaing baik itu transportasi taksi yang menggunakan Argo Meter maupun dengan hadirnya moda transportasi berbasis online seperti: Grab Car, dan Gojek. Hal ini tentu akan sangat mempengaruhi terhadap tingkat pendapatan Koperasi Taksi Bandara Ngurah Rai, oleh sebab itu maka Koperasi Taksi Bandara Ngurah Rai dianggap perlu untuk melakukan evaluasi mengenai strategi pemasaran yang harus diterapkan. Penelitian ini nantinya bertujuan untuk melakukan evaluasi dan juga merumuskan sebuah strategi baru bagi Koperasi Taksi Bandara Ngurah Rai untuk meningkatkan penjualan. Mencermati hal tersebut, maka perlu dilakukan analisis mengenai strategi pemasaran di Koperasi Taksi Bandara Ngurah Rai sehingga menjadi pedoman atau acuan bagi manajemen dalam menjalankan usahanya. Analisis dilakukan dengan menggunakan metode BCG (Boston Consulting Group) dan Matriks SWOT. 


\section{METODE PENELITIAN}

Pada penelitian ini yang menjadi variabel adalah mengenai Strategi Pemasaran meliputi STP, Segmenting (Segmentasi Pasar), Targeting (Pasar Sasaran), Positioning (Posisi Pasar). Variabel Lingkungan Internal Marketing Mix (Bauran Pemasaran) yang indikatornya adalah 7P meliputi produk, harga, saluran distribusi, promosi, personal, bukti fisik, proses. Variabel Lingkungan Eksternal meliputi analisis pasar, analisis kompetitor, analisis pemasok, analisis pemerintah, analisis teknologi dan analisis Matriks BCG (Boston Consulting Group) mengenai tingkat pertumbuhan pasar data yang dibutuhkan adalah data volume jumlah penumpang berdasarkan data jumlah Bill (nota pembayaran) yang dibayar oleh penumpang yang menggunakan jasa angkutan dari Koperasi Taksi Bandara Ngurah dari 20122016 dan analisis pangsa pasar relative yaitu bagian penjualan industri total sebuah perusahaan disebuah pasar tertentu. Data yang dibutuhkan adalah data penjualan tahun 2016 Koperasi Taksi Bandara Ngurah Rai dan data penjualan tahun Blue Bird Taxi Jimbaran. Teknik pengumpulan data yaitu: obeservasi langsung ke tempat penelitian yakni Kantor Koperasi Taksi Bandara Ngurah Rai dan Outlet Operasional di Bandara Ngurah Rai, wawancara langsung kepada informan yaitu pihak Koperasi Taksi Bandara Ngurah Rai yang dianggap mampu memberikan informasi yang dibutuhkan, kuesioner dengan metode skala likert, dokumentasi dan studi kepustakaan.

Adapun penentuan jumlah sampel wisatawan berpedoman pada teknik penentuan jumlah sampel dari Ferdinand dalam Suhban (2006), karena dalam penelitian ini terdapat 10 indikator dari lingkungan internal, maka jumlah sampel yang digunakan adalah jumlah sampel minimal 10 × $5=50$ Responden, sedangkan pengampilan sampel secara purposive sampling yaitu cara penentuan sampel yang didasarkan atas tujuan tertentu juga berdasarkan pertimbangan peneliti, dimana sampel ditetapkan sesuai dengan tujuan penelitiannya, dan memiliki kriteria (Kusmayadi, 2002).
Teknik analisis data yang digunakan dalam penelitian ini yaitu analisis deskriptif kualitatif dan deskriptif kuantitatif. Analisis deskriptif kualitatif digunakan untuk menggambarkan proses kegiatan usaha dan penentuan alternatif strategi perusahaan sedangkan analisis identifikasi faktor-faktor internal dan eksternal, serta penentuan prioritas strategi perusahaan menggunakan analisis secara kualitatif dan kuantitatif.

\section{HASIL DAN PEMBAHASAN}

Koperasi Taksi Bandara Ngurah Rai merupakan angkutan transpotasi resmi yang pertama kali beroperasi di Bandara Ngurah Rai sejak tahun 1979. Sampai saat ini koperasi Taksi Bandara Ngurah Rai masih tetap eksis beroperasi di Bandara Ngurah Rai. Koperasi Taksi Bandara Ngurah Rai menjadi salah satu usaha transportasi yang melayani kebutuhan masyarakat maupun wisatawan yang tiba di Bandara Ngurah Rai yang hendak melakukan kegiatan wisata di Pulau Bali. Untuk

memudahkan layanan transportasi bagi wisatawan, Koperasi Taksi Bandara Ngurah Rai membuka counter pelayanan di terminal kedatangan domestik Bandara Ngurah Rai.

Perusahaan pesaing dalam penelitian ini yaitu perusahaan Blue Bird Taxi kantor cabang Jimbaran, dipilihnya perusahaan ini karena merupakan pesaing terbesar dan berada dalam satu wilayah operasioanl yaitu di Kabupaten Badung, Bali. Blue bird Taxi Jimbaran memiliki kantor pusat di Jakarta berdiri pada tahun 1972, oleh pendirinya almarhumah Nyonya Mutiara Djoko Soetono dan anaknya, Chandra Suharto dan Purnomo Prawiro.

\section{Strategi Pemasaran Koperasi Taksi Bandara Ngurah Rai Bali Segmentasi Pasar (Segmenting)}

Menurut Rangkuti (2002) segmentasi adalah tindakan mengidentifikasikan dan membentuk kelompok pembeli atau konsumen secara terpisah. Segmentasi pasar pada dasarnya adalah membagi pasar sesuai dengan perilaku konsumen (penumpang taksi), baik berdasarkan kualitas pelayanan yang diinginkan, harga yang diinginkan, fasilitas dan perlengkapan yang diperlukan. Koperasi Taksi Bandara Ngurah Rai harus melakukan segmentasi pasar yang bertujuan untuk mengoptimalkan kemampuan Koperasi Taksi dalam melayani pasar sasaran. Ada beberapa 
hal yang menjadi dasar bagi Koperasi Taksi Bandara Ngurah Rai dalam menentukan segmentasi pasar, seperti segmentasi geografis, demografis dan perilaku

\section{Segmentasi Geografis}

Segmentasi geografis merupakan suatu cara perusahaan dalam membagi berdasarkan letak geografis yang berbeda, seperti Negara, Kota, Provinsi dan wilayah. Adapun segmentasi geografis wisatawan yang memiliki jumlah terbesar yaitu yang berasal dari Pulau Jawa sebesar 19 orang nilai persentase sebesar 38\%. Kemudian diikuti dari Pulau Sumatera sebesar 16 orang nilai persentase sebesar 32\%. Berasal dari Pulau Sulawesi yaitu sebesar 6 orang nilai persentase $12 \%$. Jumlah wisatawal dari NTT sebesar 5 orang nilai persentase $10 \%$. Kemudian dari Pulau Kalimantan berjumlah 2 orang nilai persentase sebesar $4 \%$.. Sementara itu yang paling kecil dari pulau NTB dan Papua masing-masing berjumlah 1 orang nilai persentasi masing-masing sebesar $2 \%$. Jumlah wisatawan yang menggunakan jasa Koperasi Taksi Bandara Ngurah Rai secara keseluruhan yaitu berjumlah 50 orang yang digunakan sebagai responden dalam penelitian ini.

\section{Segmentasi Demografis}

Segmentasi demografis membagi pasar berdasarkan variabel kependudukan, seperti umur, jenis kelamin, pendidikan, status pekerjaan dan lain sebagainya. Dengan adanya penerapan segmentasi demografis, maka Koperasi Taksi Bandara Ngurah Rai dapat merancang pasar sasaran (targeting) kepada calon konsumen atau wisatawan. Adapun hasil segmentasi demografis yaitu jenis kelamin yang terbesar menggunakan jasa layanan transportasi Taksi Bandara Ngurah Rai adalah jenis kelamin pria dengan jumlah wisatawan sebesar 29 orang dengan nilai persentase sebesar 58\%. Dari kelompok umur, jumlah wisatawan terbesar yang menggunakan jasa layanan transportasi Taxi Ngurah Rai yaitu berasal dari usia 17-30 tahun dengan jumlah wisatawan sebesar 31 orang dan nilai persentase sebesar $62 \%$. Dari status pekerjaan diperoleh jumlah wisatawan terbesar yaitu dari pegawai swasta dan Pelajar/Mahasiswa masing-masing memiliki jumlah yang sama sebesar 20 orang dengan nilai persentase masing-masing sebesar $40 \%$.

\section{Segmentasi Perilaku}

Segmentasi perilaku membagi kelompok berdasarkan perilaku konsumen dan pengelompokan pasar yang didasarkan kepada tingkah laku pembeli, seperti peristiwa, manfaat, status pemakai, tingkat pemakaian, status kesetiaan, tahap kesiapan membeli, dan sikap terhadap produk. Adapun hasil penelitian mengenai segmentasi perilaku wisatawan yang menggunakan jasa transportasi Koperasi Taksi Bandara Ngurah Rai adalah wisatawan dengan intensitas berkunjung ke Bali sebanyak 2-4 kali, termasuk dalam kategori jarang yaitu sebanyak 24 orang wisatawan dengan nilai persentase $48 \%$.

\section{Pasar Sasaran (Targeting)}

Pasar sasaran (targeting) berdasarkan letak geografis dan daya beli dari pasar yang ada. Segmentasi pasar yang dipilih yaitu wisatawan domestik maka target pasarnya yaitu wisatawan yang berasal dari Indonesia. Berdasarkan psikografis Koperasi Taksi Bandara Ngurah Rai menerapkan pasar sasaran yaitu wisatawan kelas menengah keatas.

\section{Posisi Pasar (Positioning)}

Posisi pasar Koperasi Taksi Bandara Ngurah Rai mengambil pendekatan berdasarkan manfaat (benefit positioning), dengan memberikan kemudahan bagi wisatawan atau konsumen dalam melakukan perjalanan wisata di Bali seperti dengan memberikan jasa layanan transportasi kepada wisatawan dan juga para sopir Koperasi Taksi Bandara Ngurah Rai telah di bekali dengan wawasan pariwisata Bali sehingga diharapkan dapat lebih komunikatif dan informatif memberikan informasi tentang objek-objek wisata yang menarik untuk dikunjungi.

\section{Analisis Lingkungan Internal Perusahaan Koperasi Taksi Bandara Ngurah Rai}

Lingkungan internal perusahaan mencakup product, price,place, people, promotion, physical evidence, dan process. Strategi pemasaran yang dapat dilakukan oleh Koperasi Taksi Bandara Ngurah Rai yaitu dengan menganalisis terlebih dahulu lingkungan internal (Internal Factor Analysis Summary) IFAS, maka harus menghitung rating, bobot dan skor yang didapat dari hasil kuesioner yang dibagikan kepada 50 
wisatawan dan 5 (lima) orang akademisi di bidang pemasaran.

Berdasarkan hasil penghitungan rating, bobot, dan skor lingkungan internal yang menjadi kekuatan adalah yang memiliki rating paling tinggi yaitu kemampuan sopir dalam berkomunikasi dengan baik dan ramah sebesar 3,36 . Kemudian pelayanan jasa transportasi yang diberikan kepada penumpang mendapatkan rating 3,28. Kemampuan sopir dalam berkendara sangat mempengaruhi kepuasan wisatawan dimana kemampuan sopir mendapat nilai sebesar 3,24. Pengetahuan Sopir mengenai informasi pariwisata Bali mendapat nilai sebesar 3,3. Kebersihan dan kenyamanan transportasi selama melayani wisatawan mendapat nilai 3,04. Seragam karyawan dan sopir juga sangat mempengaruhi dalam meningkatkan kepuasan terhadap wisatawan dengan nilai sebesar 3,04. Kemudahan untuk menemukan lokasi kounter Taksi di Bandara Ngurah Rai mendapat nilai sebesar 3,18. Hal terakhir yang menjadi kekuatan yaitu kemudahan dalam melakukan pemesanan dan pembayaran jasa angkutan Taksi dengan rating 3,1.

Untuk faktor internal, kelemahan yang terdapat pada Koperasi Taksi Bandara Ngurah Rai yaitu harga jasa angkutan taksi mendapat rating 2,24, variabel tersebut sebagai faktor kelemahan karena harga yang ditawarkan masih terbilang tinggi. Selanjutnya kurangnya promosi yang dilakukan mendapat rating sebesar 2,34, masih kurangnya promosi untuk pengembangan pangsa pasar.

Berdasarkan penilaian responden terhadap analisis faktor internal (internal factor analysis) yaitu faktor kekuatan dan faktor kelemahan perusahaan tersebut diatas, maka diperoleh skor total sebesar 2,66. Skor ini menunjukkan bahwa posisi internal perusahaan cukup kuat untuk bersaing karena berada di atas nilai rata-rata yaitu 2,5.

\section{Analisis Lingkungan Eksternal Perusahaan Koperasi Taksi Bandara Ngurah Rai}

Strategi pemasaran yang dapat dilakukan oleh Koperasi Taksi Bandara Ngurah Rai yaitu dengan menganalisis terlebih dahulu lingkungan eksternal, maka harus menghitung rating, bobot dan skor yang didapat dari hasil kuesioner yang dibagikan kepada 5 (lima) orang karyawan Koperasi Taksi Bandara Ngurah Rai dan 5 (lima) orang akademisi di bidang pemasaran.
Berdasarkan hasil penghitungan rating, bobot, dan skor lingkungan eksternal, peluang tertinggi yang akan dimiliki oleh Koperasi Taksi Bandara Ngurah Rai adalah peningkatan jumlah kunjungan wisatawan dengan rating sebesar 3,6. Selanjutnya adanya perkembangan alat komunikasi dan berkembangnya media internet sebagai sumber informasi sama-sama mendapat rating 3,4. Selanjutnya pemerintah mengeluarkan regulasi yang berkaitan dengan sektor pariwisata dan kerjasama perusahaan Taksi Bandara Ngurah Rai dengan sektor industri pariwisata (hotel, restoran daya tarik wisata) sama-sama mendapatkan rating sebesar 3,2.

Faktor eksternal yang merupakan ancaman yang akan dihadapi oleh perusahaan yaitu nilai tukar rupiah yang melemah mendapat rating 2,0. Selanjutnya adanya krisis ekonomi global mendapatkan rating sebesar 1,8. Lalu adanya kenaikan harga BBM dan pertumbuhan perusahaan transportasi taxi mendapatkan nilai rating yang sama sebesar 1,6. Terakhir adalah berkembangnya transportasi online mendapat rating paling kecil yakni sebesar 1,2.

Berdasarkan penilaian responden terhadap analisis faktor eksternal yaitu faktor peluang dan faktor ancaman perusahaan tersebut diatas, maka diperoleh skor total sebesar 2,28. Skor ini menunjukkan bahwa posisi eksternal perusahahaan belum baik karena dibawah skor rata-rata yaitu 2,5.

\section{Penentuan Matriks Internal dan Eksternal}

Matrik IE digunakan untuk menganalisis posisi perusahaan. Hasil dari penilaian matriks IE untuk Koperasi Taksi Bandara Ngurah Rai dapat dilihat pada diagram 4.1. Nilai total IFAS sebesar 2,66 dan EFAS sebesar 2,28 menunjukkan posisi Koperasi Taksi Bandara Ngurah Rai berada pada sel V. Pada posisi ini strategi yang diterapkan yaitu growth strategy yaitu perusahaan harus menetapkan upayaupaya dalam memperkuat pangsa pasar, meningkatkan penjualan, mengejar laba yang besar dengan upaya diversivikasi/perluasan pasar.

\section{Analisis Strategi Pemasaran Dengan Metode BCG (Boston Consulting Group)}

Matriks $B C G$ memiliki empat kuadran, yaitu stars, question mark, cash cow dan dogs. Untuk mengetahui tingkat pertumbuhan pasar dibutuhkan data jumlah penumpang Koperasi 
Taksi Bandara Ngurah Rai Bali berdasarkan Bill (nota pembayaran) pada tahun 2012-2016. Berdasarkan penghitungan matriks $B C G$ di atas, diketahui tingkat pertumbuhan pasar pada Koperasi Taksi Bandara Ngurah Rai tahun 2012 hingga 2016 adalah $(20,2 \%+21,6$ $\%+(-24,47 \%)+(-11,93 \%) / 4=1,35 \%$. Koperasi Taksi Bandara Ngurah Rai memiliki pertumbuhan pasar yang rendah.

\section{Analisis Pangsa Pasar Pada Koperasi Taksi Bandara Ngurah Rai}

Analisis pangsa pasar menunjukkan besarnya pangsa pasar dari volume penjualan Koperasi Taksi Bandara Ngurah Rai dibandingkan dengan pesaingnya yaitu PT Blue Bird Taxi Jimbaran. Data Jumlah penumpang Koperasi Taksi Bandara Ngurah Rai tahun 2016 dan PT Blue Bird Taxi Jimbaran tahun 2016. Berdasarkan penghitungan matriks $B C G$ untuk mengetahui pangsa pasar relatif (relative market share) diketahui pangsa pasar relatif Koperasi Taksi Bandara Ngurah Rai tahun 2016 dibanding dengan pesaingnya PT Blue Bird Taxi Jimbaran sebesar 1,45 $\mathrm{x}>1$.

\section{Analisis Posisi Matriks BCG (Boston Consulting Group) Pada Koperasi Taksi Bandara Ngurah Rai}

Berdasarkan hasil penghitungan tingkat pertumbuhan pasar di peroleh nilai sebesar $1,35 \%$ dimana tingkat pertumbuhan pasar masih rendah pada Koperasi Taksi Bandara Ngurah Rai. Penghitungan pangsa pasar relatif pada tahun 2016 didapat hasil sebesar 1,45 x > 1. Berdasarkan diagram matriks $B C G$ posisi Koperasi Taksi Bandara Ngurah Rai pada tahun 2016 jika dibandingkan dengan pesaingnya berada pada posisi Sapi Perah/Cash Cow. Posisi ini menunjukkan Koperasi Taksi Bandara Ngurah Rai memiliki tingkat pertumbuhan pasar yang rendah namun memiliki pangsa pasar yang lebih tinggi dari pesaingnya yaitu Blue Bird Taxi Jimbaran.

Pada kuadran Cash Cow ini perusahaan harus meningkatkan jumlah penjualan agar perusahaan tetap dalam posisi yang kuat dan memenangkan persaingan pasar. Adapun strategi pemasaran yang dapat dilakukan adalah dengan cara memelihara pasar yaitu meningkatkan kualitas pelayanan supaya para konsumen tetap setia menggunakan jasa layanan Taksi Bandara Ngurah Rai, menciptakan produk baru atau inovasi produk seperti menambah fasilitas hiburan (Majalah, $T V$, Radio) didalam taksi..

Penjelasan di atas dapat disimpulkan bahwa penelitian ini mendukung penelitian yang dilakukan oleh Alfin Surya Pratama (2016) yang menyatakan bahwa untuk memenangkan persaingan dalam pasar maka perlu menentukan strategi pemasaran perusahaan berdasarkan posisi bersaing dengan menggunakan pendekatan BCG (Boston Consulting Group) dan juga Analisis SWOT digunakan untuk menyikapi persaingan dengan menganalisis lingkungan internal dan eksternal perusahaan.

\section{Alternatif Strategi Pemasaran}

Prioritas strategi pemasaran yang direkomendasikan untuk Koperasi Taksi Bandara Ngurah Rai, yaitu.

1. Meningkatkan citra perusahaan dimata konsumen dengan cara memberikan pelayanan yang lebih bermutu dan berkualitas dan mempertahankan tingkat harga yang lebih kompetitif sesuai dengan kualitas pelayanan yang diberikan.

2. Meningkatkan kualitas SDM dengan memberikan pelatihan secara berkala kepada para karyawan, seperti pelatihan peningkatan standarisasi kinerja, pelatihan mengenai wawasan pariwisata Bali meliputi pengenalan objek-objek wisata, pusat perbelanjaan dan hiburan, dan juga memberikan insentif/penghargaan atas prestasi kerja mereka Kegiatan-kegiatan tersebut harus lebih di efektifkan demi terwujudnya kepuasan pelanggan dalam hal ini penumpang yang menggunakan jasa taksi Bandara Ngurah Rai.

3. Meningkatkan kerjasama dengan usaha pariwisata seperti : Hotel yaitu menjadi mitra tetap sebuah hotel dalam menangani urusan transportasi tamu hotel tersebut menjemput dan mengantar ke Bandara, pusat perbelanjaan dengan menjadi mitra tetap dimana koperasi Taksi Bandara akan merekomendasikan pusta perbelanjaan tersebut kepada penumpangnya dan juga objek wisata seperti objek wisata kuliner dimana sopir taksi akan membawa tamu atau penumpang taksi ke tempat wisata kuliner yang menjad mitra resmi dari koperasi Taksi Bandara Ngurah Rai. 
4. Meningkatkan promosi secara Online dengan cara membuat web atau melalui jejaring-jejaring sosial supaya para konsumen dapat dengan mudah memperoleh pelayanan jasa transportasi yang disediakan oleh Koperasi Taksi Bandara Ngurah Rai.

5. Mempertahankan kualitas produk serta melakukan inovasi dan pengembangan produk jasa yang ditawarkan yaitu dengan merancang sebuah aplikasi pemesanan jasa layanan Koperasi Taksi Bandara Ngurah Rai oleh pengguna Gadget Smart Phone, menyediakan minuman atau makanan ringan bagi konsumen menyediakan fasilitas hiburan didalam Taksi (TV, Radio) dan majalah atau koran sebagai bahan bacaan, menyediakaan sumber arus untuk mengisi daya HP, dan fasilitas free WiFi.

\section{SIMPULAN DAN SARAN Simpulan}

Sesuai analisis matriks BCG berdasarkan tingkat pertumbuhan industri dan pangsa pasar relative, Koperasi Taksi Bandara Ngurah Rai berada pada kuadran cash cow, dimana tingkat pertumbuhan pasar di peroleh nilai sebesar $1,35 \%$ dan penghitungan pangsa pasar relatif pada tahun 2016 didapat hasil sebesar 1,45 $\mathrm{x}>1$. Menunjukkan bahwa pertumbuhan pasar yang rendah namun memiliki pangsa pasar yang lebih tinggi dari pesaingnya.

Hasil analisis SWOT berdasarkan lingkungan internal dan eksternal Koperasi Taksi Bandara Ngurah Rai Bali bahwa total skor dari analisis matriks IFAS adalah 2,66 skor ini menunjukkan bahwa perusahaan cukup kuat secara internal dalam bersaing karena telah mampu memanfaatkan kekuatan dalam mengatasi kelemahan yang dimilikinya dengan baik. Total skor dari analisis matriks EFAS adalah 2,28, skor ini menunjukkan bahwa posisi eksternal perusahaan belum baik karena dibawah skor rata-rata 2,5.

Strategi Pemasaran Koperasi Taksi Bandara Ngurah Rai, dengan melakukan Segmentasi pasar berdasarkan perilaku konsumen, menentukan pasar sasaran berdasarkan letak geografis yaitu wisatawan Indonesia yaitu pasar sasaran masyarakat kelas menengah ke atas dan menentukan posisi pasar dilakukan dengan pendekatan berdasarkan manfaat (benefit positioning).

\section{Saran}

1. Koperasi Taksi Bandara Ngurah Rai harus meningkatkan kualitas pelayanan dengan cara memberikan pelayanan yang cepat dan efisien mulai dari proses pemesanan taksi sampai menghantarkan ke tempat tujuan.

2. Koperasi Taksi Bandara Ngurah Rai harus melakukan inovasi produk baru agar pasar tidak jenuh seperti merancang sebuah sistem apikasi pemesanan Koperasi Taksi Bandara Ngurah Rai, menyediakan air mineral, menyediakan majalah untuk dibaca, menyediakan sumber arus listrik untuk mengisi daya Handphone, menyediakan internet gratis/ free Wifi

3. Fasilitas yang masih kurang dan belum memenuhi standar harus terus ditambah dan diperbaiki seperti mengganti kendaraan yang sudah tua, mengganti kursi sofa yang sudah buruk.

4. Frekuensi kegiatan promosi secara berkesinambungan perlu ditingkatkan melalui pemanfaatan media sosial seperti Facebook, Twitter, Instagram dan alamat Website, pemasangan billboard atau papan iklan di tempat-tempat strategis dan mudah dilihat.

5. Koperasi Taksi Bandara Ngurah Rai perlu meningkatkan kualitas SDM (Sumber Daya Manusia) melalui pemberian pelatihan secara terjadwal yang berkaitan dengan pekerjaan maupun motivasi, pengembangan karir, meningkatkan standarisasi kerja, dan memberikan insentif sehingga produktivitas mereka meningkat serta dapat bekerja dan memberikan pelayanan terbaik 


\section{Kepustakaan}

Anonim. 2014. Data Jumlah Kunjungan Wisatawan Mancanegara ke Bali. Dinas Pariwisata Bali.

Augusty, Ferdinand. 2006. Metode Penelitian Manajemen: Pedoman Penelitian Untuk Skripsi, Tesis dan Disertasi Ilmu Manajemen. Semarang: Badan Penerbit Universitas Diponegoro.

Kotler, Philip, Armstrong, Gary. 2012. Prinsip-Prinsip Pemasaran. Jakarta: Erlangga.

Kusmayadi dan Endar Sugiarto. 2000. Metodologi Penelitian dalam Bidang Kepariwisataan. Jakarta: Gramedia Pustaka Utama.

Pratama, Alfin Surya. 2016. Analisis Strategi Pemasaran Roti Mandiri Dengan Pendekatan Metode Boston Consulting Group (BCG), SWOT dan Benchmarking. Diploma thesis, Universitas Muhammadiyah Surakarta.

Rangkuti, Freddy. 2006. Analisis Swot Teknik Membedah Kasus Bisnis, Jakarta: PT Gramedia Pustaka Utama.

Sugiono, dkk. 2003. Teknik Sampling. Jakarta : PT. Gramedia Pustaka Utama. . 2014. Metode Penelitian Kuantitatif, Kualitatif dan $R \& D$.Bandung: Alfabeta.

Tjiptono, Fandy. 1997. Strategi Pemasaran. Yogyakarta: Andi Offset. 